\section{特集 : 光防除の最前線}

\section{ミカンキジラミ Diaphorina citri 成虫 （カメムシ目：ヒラズキジラミ科）の定位に 対する紫外線除去フィルムの効果}

\author{
上地 奈美 $*$ \\ (独) 農業・食品産業技術総合研究機構果樹研究所
}

\begin{abstract}
Effects of UV-Absorbing Film on the Orientation of Diaphorina citri (Hemiptera: Liviidae) Adults. Nami Uechi ${ }^{*}$ NARO Institute of Fruit Tree Science; Fujimoto 2-1, Tsukuba, Ibaraki 305-8605, Japan. Jpn. J. Appl. Entomol. Zool. 59: 14-16 (2015)

Abstract: The Asian citrus psyllid, Diaphorina citri Kuwayama, transmits pathogenic bacteria that cause the citrus greening disease (Huanglongbing). To examine an effective method to reduce the orientation of $D$. citri adults, the effect of a UV-absorbing film was compared with that of a normal film in the laboratory. The number of adults oriented under the UV-absorbing film was significantly fewer than those under the normal film. The UV-absorbing film is could be used as a physical pest control material against Diaphorina citri.
\end{abstract}

Key words: Diaphorina citri; orientation; UV-absorbing film; phototaxis

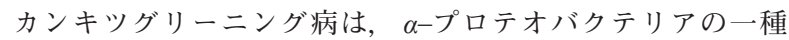
'Candidatus Liberibacter spp.'によって引き起こされるカンキッ の重要病害で, 世界中の主要なカンキッ栽培地で甚大な被害をも たらしている (da Graça, 1991)。世界中で発生地域が拡大を続け ており，アメリカ合衆国では2005 年に初めてフロリダ州で本病 の発生が確認されて以降, ルイジアナ州, サウスカロライナ州, ジョージア州抢よびテキサス州に分布を拡大し，さらに，2012 年 には，カンキッ類の最大生産州の 1 つであるカリフォルニア州で 発生している (CDFA, 2012)。我が国では 1988 年に西表島での発 生を確認し (Miyakawa and Tsuno, 1989)，その後，沖縄県のほほ 全域（渡久地 ·河野, 1997）と鹿児島県の喜界島, 徳之島, 沖永 良部島，与論島に打いて発生し，防除が進められている（橋元ら, 2006)。緊急的・集中的な防除により，北限の喜界島では2013 年にグリーニング病の根絶宣言が発表された（農林水産省門司植 物防疫所, 2012). 現在のところ，グリーニング病の実用的な治 療法は確立されておらず, 罹病樹の早期発見と除去, 媒介虫であ るミカンキジラミの防除などが主な対策である.

本病害を媒介するミカンキジラミ Diaphorina citri Kuwayama (カメムシ目：ヒラズキジラミ科) はミカン科のカンキツ類 Citrus spp. やゲッキツ Murraya paniculata（L.） Jack. を寄主とし，アジ アの熱帯〜温帯域, 南北アメリカ大陸などのカンキツ栽培地域に
広く分布する (Halbert and Manjunath, 2004). わが国では奄美大 島以南の南西諸島に分布していたが (Miyatake, 1965)，近年では 鹿児島県の屋久島や九州本土の指宿市でも発生が確認された (牛 牧, 2002 ; 井上, 2007)。本種の防除はもっぱら殺虫剂散布によ るものであるが，大量の薬剤散布による環境への負荷や抵抗性発 達の可能性が懸念されるため, 今後の持続的な管理のためにも, 使用薬剤量低減が求められている.

物理的防除資材である紫外線除去フィルムは栽培施設への 害虫類の飛来侵入を阻止することが知られている (Shimoda and Honda, 2013). カンキツ類は主に露地の園地で栽培されるが，グ リーニング病対策のため苗は平張りの網室で育苗されている。も し，紫外線除去フィルムがミカンキジラミに対しても飛来侵入の 抑制効果が認められるのであれば，フィルムの被覆により，より 安定的な健全苗の生産が可能となると考えられる。そこで，本研 究では，紫外線除去フィルムのミカンキジラミ成虫に対する定位 抑制効果を検討した。 なお，本研究は，農林水産省委託研究プロ ジェクト「生物の光応答メカニズムの解明と省エネルギー, コス 卜削減技術の開発」のうち,「害虫の光応答メカニズムの解明と 高度利用技術の開発（INSECT-3109）」の予算で実施された.

\section{材料および方法}

\section{1. 供試虫および植物}

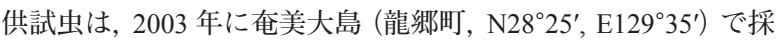
集し, 果樹研究所内の温室内 $\left(20 \sim 40^{\circ} \mathrm{C}\right)$ に扎いてゲッキッの実 生苗 (5〜7 年生) で継代飼育しているミカンキジラミの成虫を用 いた，実験に用いたゲッキツの実生苗 (1, 2 年生) は沖縄県で種 子を採集し, 果樹研究所内の温室内 $\left(20 \sim 40^{\circ} \mathrm{C}\right)$ で播種, 栽培し たものである.

\section{2. 定位試験}

側面をメッシュ張りにした箱 $(50 \mathrm{~cm} \times 20 \mathrm{~cm} \times 20 \mathrm{~cm})$ で定位試 験を行った，箱の上部には，赤外線カットガラス（五鈴精工硝子 (株)）で蓋をして，上面の半分を厚さ $1 \mathrm{~mm}$ の紫外線除去フィル ム (カットエース, 光洋化学(株)), もう半分を, 紫外線を透過 する厚さ $1 \mathrm{~mm}$ のフィルム (キリナイン，三菱樹脂アグリドーム (株)，以後，通常フィルム）で覆った (Fig. 1)。ガラス蓋の上方 から蛍光灯 (バイタライト, 40W 型, Light Sources 社, USA) 4 本 を照射した。 バイタライトは中近紫外線から可視光線にかけて， CIE（国際照明委員会）が標準化した平均正午の太陽光 (色温度： $5500 \mathrm{~K}, \mathrm{CIE}$ 昼光）の分光分布に近似するよう設計されている蛍 光灯である (Marutoki Limited, 2013)。箱内部の両端にはゲッキ ツの実生苗を設置し，ミカンキジラミ成虫の移動打よび定位を 促した。ミカンキジラミは寄主植物への定着性が強く，いった ん寄主に定位するとほとんど再移動しないことが示唆されてい

日本応用動物昆虫学会誌 (応動昆) 第 59 巻 第 1 号：14-16 (2015)

http://odokon.org/

*E-mail: uechinmi@affrc.go.jp

2014 年 11 月 13 日受領 (Received 13 November 2014)

2014 年 12 月 16 日登載決定 (Accepted 16 December 2014)

DOI: $10.1303 /$ jjaez.2015.14 
A

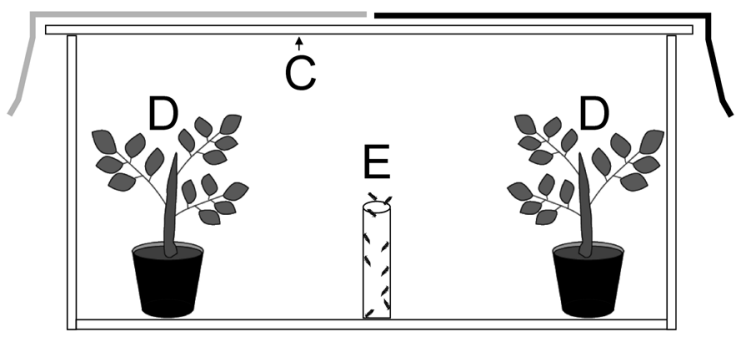

Fig. 1. Diagram of the observation system used in this study. A: UV-absorbing film, B: normal film; C: infrared-absorbing glass; D: sapling of Murraya paniculata; E: Vial with Diaphorina citri adults.

る (Kobori et al., 2011)。飛翔能力もそれほど高くなく, 短い飛翔 を繰り返したり，風に乗ることにより移動する (坂巻, 2005 ; 荒 川・宮本, 2007)。 また, 今回の予備試験において, 寄主植物上 に定位した個体が短時間で飛び立つことはほとんどなかったた め, 本実験においてもいったんゲッキッ上に定位した個体はそこ から飛び立って移動することはないと想定して実験を行った。

羽化後 1 週間〜 30 日程度のミカンキジラミ雌雄成虫計 30 頭 を，ポリスチレン製バイアルに回収した後，水草用二酸化炭素ス プレー (テトラジャパン(株)) をごく短時間噴射して動きを止め, バイアルごと箱の中央に静置した. 24 時間後に紫外線除去フィ ルム側のゲッキッに定位した個体数と，通常フィルム側のゲッキ ツに定位した個体数を記録し，それぞれ，紫外線除去フィルム側 と通常フィルム側への定位個体数とした。網箱は外光を遮断した 実験室内に設置し, 部屋の温度は $25 \pm 3^{\circ} \mathrm{C}$, 湿度は $40 \sim 60 \%$ に 保った. 実験は午前 9 12 時に開始し, 実験中は蛍光灯を常に点 灯した. 反復は 4 回繰り返し, 反復ごとに紫外線除去フィルムと 通常フィルムの位置を入れ替え, 設置位置の影響を排除した。紫 外線除去フィルム側への平均定位個体数と通常フィルム側の平 均定位個体数を求め, $t$ 検定を行った。 また, データロガー（TR74Ui，ティアンドディ(株)）を用いて，紫外線除去フィルム打よ び通常フィルム下の照度 (lux) と 260 400 nm の範囲の UV 量 $\left(\mathrm{mW} / \mathrm{cm}^{2}\right)$ を 2 回ずつ測定し, 平均值を求めた.

\section{結果と考察}

通常フィルム側の平均定位個体数は $24.8( \pm 0.5$, 標準誤差 $)$ で あったのに対し, 紫外線除去フィルム側の平均定位個体数は 1.5 $( \pm 0.4$, 標準誤差 $)$ で, 有意な差が認められた $(t=-10.93, \mathrm{df}=6$, $p=0.000034$, Fig. 2). また, 照度と UV 量は, 通常フィルム下で は，それぞれ, $4,000 \mathrm{~lx}$ と $0.010 \mathrm{~mW} / \mathrm{cm}^{2}$ だったのに対し，紫外線 除去フィルム下では $3,8841 \mathrm{~lx}$ で通常フィルムの $97.1 \%$ であり, UV 量は $0.000 \mathrm{~mW} / \mathrm{cm}^{2}$ であった. 紫外線除去フィルム側の平均定位 個体数が著しく少なかった理由として, 紫外線除去フィルムがミ カンキジラミに対して定位抑制効果がある可能性が考えられる. オンシッコナジラミ Trialeurodes vaporariorum (Westwood) では, フィルムで被覆していない部分から紫外線除去フィルム被覆下へ

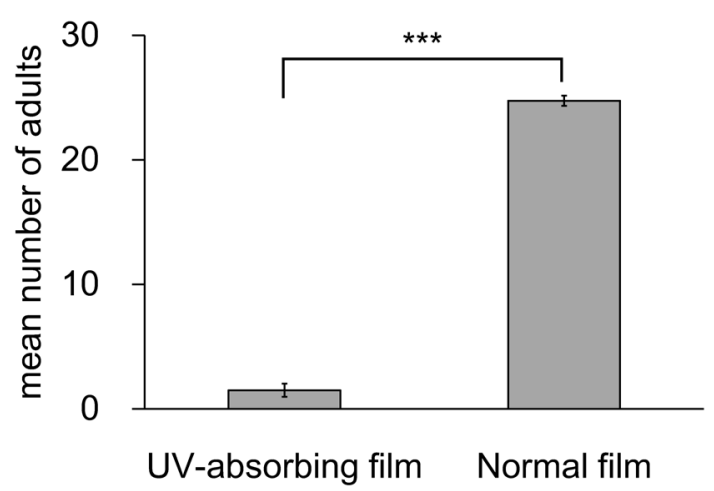

Fig. 2. Mean number of Diaphorina citri adults oriented on the saplings of Murraya paniculata under UV-absorbing and normal films. Asterisks indicate a significant difference between UV-absorbing and normal films in the number of adults $(t=$ $-10.93, \mathrm{df}=6, p=0.000034)$. Error bar indicates the standard error.

の成虫の移動が少なく, 紫外線除去フィルムによる分散抑制効 果が示唆されている (太田・武田, 2014)。ミミカンキジラミはコ ナジラミ類と同じカメムシ目の微小害虫であるため, 紫外線除去 フィルムに移動分散を伴う定位抑制効果がある可能性が高いと考 えられるが，確実に定位抑制効果を調べるためには，太田・武田 （2014）でなされたような，フィルムに覆われていない部分と紫 外線除去フィルムあるいは通常フィルム被覆下との比較実験を実 施することが必要だと考えられ, 今後の課題である. また, 行動 に対する光条件の要因として, 波長や強度, 偏光などの属性が考 えられる (弘中・針山, 2014) ことから, 紫外線除去フィルムが ミカンキジラミの定位に与える影響の要因を明らかにするには, さらに波長別の誘引試験なども実施する必要がある.

ミカンキジラミ打よびグリーニング病の発生地では, カンキ ッはほとんどが露地で栽培されている. しかし, グリーニング病 フリー苗は平張りの網室で育苗されていることや, 台風被害や鳥 獣害の被害を軽減し, 生産量の安定化のために施設栽培の導入が 推進されている(沖縄県農林水産部, 2013) ため, 今後はカンキ ッの施設栽培が増加する可能性もある. 紫外線除去フィルムの効 果をさらに検証することで, 栽培施設で紫外線除去フィルムがミ カンキジラミの飛び込みの低減に有効であることが実証できれ ば，グリーニング病対策としての物理的防除技術につながること が期待できる.

\section{引用文献}

荒川賢良・宮本憲治 (2007) 植防研報 43：23-26. [Arakawa, K. and K. Miyamoto (2007) Res. Bull. Plant Prot. Jpn. 43: 23-26.]

CDFA（2012） http://www.cdfa.ca.gov/egov/Press_Releases/Press_ Release.asp?PRnum=12-013

da Graça, J. V. (1991) Аnnu. Rev. Phytopathol. 29: 109-136.

Halbert, S. E. and K. L. Manjunath (2004) Fla. Entomol. 87: 330353.

橋元祥一 · 濱島朗子 · 林川修二 · 未永 博 篠原和孝・湯田達 
也・時村金愛 (2006) 植物防疫 60：298-301. [Hashimoto, S., A. Hamashima, S. Hayashikawa, H. Suenaga, K. Shinohara, T. Yuda and K. Tokimura (2006) Plant Prot. 60: 298-301.]

弘中満太郎・針山孝彦 (2014) 応動昆 58: 93-109. [Hironaka,

M. and T. Hariyama (2014) Jpn. J. Appl. Entomol. Zool. 58: 93-109.]

井上広光 (2007) 今月の農業 51：86-90. [Inoue, H. (2007) Monthly Agric. Mag. 51: 86-90.]

Kobori, Y., T. Nakata, Y. Ohto and F. Takasu (2011) Appl. Entomol. Zool. 46: 27-30.

Marutoki Limited (2013) http://www.marutoki.com/product/010. html $\# 02$

Miyakawa, T. and K. Tsuno (1989) Ann. Phytopathol. Soc. Jpn. 55: 667-670.

Miyatake, Y. (1965) Kontyû 33: 171-189.
農林水産省門司植物防疫所 (2012) 植物防疫 66：348-349. [Moji Plant Protection Station (2012) Plant Prot. 66: 348-349.]

太田 泉 - 武田光能 (2014） 応動昆 58：303-312. [Ohta, I. and M. Takeda (2014) Jpn. J. Appl. Entomol. Zool. 58: 303-312.]

沖縄県農林水産部 (2013) http://www.pref.okinawa.jp/site/norin/ engei/documents/p73-p83.pdf

坂巻祥孝 (2005) 南太平洋海域調査研究報告 42: 121-125. [Sakamaki, Y. (2005) KURCPI Occasional Papers 42: 121125.]

Shimoda, M. and K. Honda (2013) Appl. Entomol. Zool. 48: 413421.

渡久地章男 - 河野伸二 (1997) 植物防疫 51：565-570. [Toguchi, A. and S. Kawano (1997) Plant Prot. 51: 565-570.]

牛牧 昭 (2002) 九州植物防疫 582: 5. [Ushimaki, A. (2002) Kyushu Plant Protect. 582: 5.] 